\title{
A 10-year bibliometric analysis of osteosarcoma and cure from 2010 to 2019
}

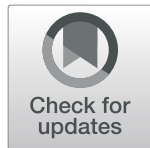

Wacili $\mathrm{Da}^{\dagger}$, Zhengbo Tao ${ }^{\dagger}$, Yan Meng ${ }^{\dagger}$, Kaicheng Wen, Siming Zhou, Keda Yang and Lin Tao

\begin{abstract}
Background: In recent decades, the 5-year survival rate of osteosarcoma remains poor, despite the variety of operations, and exploration of drug therapy has become the key to improvement. This study investigates the contribution of different aspects in osteosarcoma and cure, and predicts research hotspots to benefit future clinical outcomes.

Methods: The Web of Science and PubMed databases were queried to collect all relevant publications related to osteosarcoma and cure from 2009 to 2019. These data were imported into CiteSpace and the Online Analysis Platform of Literature Metrology for bibliometric analysis. Bi-clustering was performed on Bibliographic Item cooccurrence Matrix Builder (BICOMB) and gCLUTO to identify hotspots. Additionally, completed clinical trials on osteosarcoma with results past phase II were collated.

Results: A total of 2258 publications were identified in osteosarcoma and cure from 2009 to 2019. China has the largest number of publications (38.49\%), followed by the United States (23.03\%) with the greatest impact (centrality $=0.44$ ). The centrality of most institutions is $<0.1$, and Central South University and Texas MD Anderson Cancer Center possess the highest average citation rates of 3.25 and 2.87. BMC cancer has the highest average citation rate of 3.26 in 772 journals. Four authors (Picci P, Gorlick R, Bielack SS and Bacci G) made the best contributions. We also identified eight hotspots and collected 41 clinical trials related to drug research on osteosarcoma.
\end{abstract}

Conclusions: The urgent need exists to strengthen global academic exchanges. Overcoming multidrug resistance in osteosarcoma is the focus of past, present and future investigations. Transformation of the metastasis pattern, microenvironment genetics mechanism, alternative methods of systemic chemotherapy and exploration of traditional Chinese medicine is expected to contribute to a new upsurge of research.

Keywords: Osteosarcoma, Cure, Bibliometric analysis, Hotspots, Co-word biclustering analysis

\section{Background}

Osteosarcoma, a common primary bone malignancy in children and adolescents, occurs primarily in the metaphysis of long bones and is characterized by early lung metastasis, high mortality and poor prognosis [1]. Limited by primitive medical care, amputation was the mainstream osteosarcoma treatment, with a 5-year

\footnotetext{
* Correspondence: taolindr@163.com

'Wacili Da, Zhengbo Tao and Yan Meng contributed equally to this work. Department of Orthopedics, The First Hospital of China Medical University, 155 Nan Jing North Street, Shenyang 110001, Liaoning, China
}

survival rate of approximately $20 \%$, and the defective appearance and function of the affected limb has a serious impact on patient psychology [2]. With the rapid development of medical science and technology, limb salvage in osteosarcoma has been adopted at a rate of more than $80 \%$ in the clinic and has gradually replaced the majority of amputation cases, but the survival rate is still poor [3]. This outcome might be related to many unsolved issues, such as complex pathogenesis, lack of novel adjuvant drugs and an imperfect evaluation system. Currently, the widely accepted strategy for osteosarcoma

(c) The Author(s). 2021 Open Access This article is licensed under a Creative Commons Attribution 4.0 International License which permits use, sharing, adaptation, distribution and reproduction in any medium or format, as long as you give appropriate credit to the original author(s) and the source, provide a link to the Creative Commons licence, and indicate if changes were made. The images or other third party material in this article are included in the article's Creative Commons licence, unless indicated otherwise in a credit line to the material. If material is not included in the article's Creative Commons licence and your intended use is not permitted by statutory regulation or exceeds the permitted use, you will need to obtain permission directly from the copyright holder. To view a copy of this licence, visit http://creativecommons.org/licenses/by/4.0/ The Creative Commons Public Domain Dedication waiver (http://creativecommons.org/publicdomain/zero/1.0/) applies to the data made available in this article, unless otherwise stated in a credit line to the data. 
is surgery combined with neoadjuvant chemotherapy, which has a great capacity to shrink tumours and eliminate small lesions to ensure complete surgical resection and reduce tumour recurrence and metastasis [4]. Since the surgical method is generally determined, the key to improving the survival rate is drug therapy, which is also a difficulty and a hot issue for global orthopaedic and oncology experts.

Bibliometric analysis has become the best tool for exploring the detailed research trends in a certain field over time [5]. This analysis objectively presents the research contributions of different countries, institutions, journals and authors in scientific fields via qualitative and quantitative analysis and forecasts the research trends or hotspots. At the same time, it is worth explaining that the hotspots refer to the problems in a specific filed that has not been solved and is highly concerned by global scholars, or the research direction that needs to be broken through urgently and of great significance in the future. In addition, bibliometric analysis has also played a momentous role in formulating policy and clinical guidelines on various diseases [6]. However, no current bibliometric analysis has been conducted on osteosarcoma and cure, and even less attention has been focused on prediction of research hotspots. Our previous publications demonstrated that bi-clustering analysis has great advantages in exploring key areas of research and the related representative literature and can also be applied to verify hotspots $[7,8]$. This study aims to conduct a comprehensive investigation of the current academic status and clinical issues in osteosarcoma, with a focus on cure and chemoresistance, and to predict the potential progress in this field over the next decades. We also summarize the representative clinical trials of drug therapy for osteosarcoma.

\section{Methods}

\section{Data sources and collection}

In recent years, the Science Citation Index Expanded and the Social Science Citation Index from Thomson Reuters Web of Science have been developed as the most authoritative and widely used bibliometric analysis databases. We performed a comprehensive collection of all of the original articles and reviews from the Web of Science from 2009 to 2019 with the following retrieval strategies: osteosarcoma AND (drug OR medicine OR medication OR remedy OR chemical OR cure) AND Language $=$ English. Medical Subject Headings $(\mathrm{MeSH})$ terms are a type of standard vocabulary that can be adopted to perform continuous co-word cluster analysis and reflect the main thrust of the literature [9]. We also conducted a similar online search in PubMed based on the screening criteria of ("Osteosarcoma"[Mesh]) AND ("drug" OR "medicine" OR "medication" OR "remedy"
OR "chemical" OR "cure"), which was developed by the National Center for Biotechnology Information (NCBI) of the National Library of Medicine (NLM). No language restrictions were applied for all literature search and downloading processes, which were completed within one day on February 26, 2020 to avoid errors caused by frequent database updates. Clinical trials that had completed Phase II were obtained from ClinicalTrials.gov (https://clinicaltrials.gov/).

All data were independently collected by two authors (WCLD and SMZ) with an agreement rate that eventually reached 0.90 that implies a high degree of accordance [10]. The data obtained from Web of Science were converted to txt format and imported into CiteSpace V5.5.R1 SE, 64-bit (Drexel University, Philadelphia, PA, USA) and the Online Analysis Platform of Literature Metrology (http://bibliometric.com/) for subsequent bibliometric analysis. The data downloaded from PubMed were uploaded to Bibliographic Item cooccurrence Matrix Builder (BICOMB), a tool for hotspot analysis [11].

\section{Statistical methods}

First, we analysed and summarized all kinds of indicators, including countries, institutions, journals, authors, $\mathrm{H}$ index and impact factor (IF) of the version (2019) of Journal Citation Reports (JCR) for all publications. Moreover, the annual publication quantities and growth trends of different countries/regions were found through the online bibliometric platform. CiteSpace was used to identify the collaborations among countries, institutions and authors. A co-occurrence analysis of the keywords was performed to predict research frontiers and new trends. The method of "time slicing" was also performed in CiteSpace, where we were free to set the years and the number of summarized papers for each slice. As for our analysis strategy was extracting the first top 50 papers in a year slice into a single network [7]. Depending on the purpose of our analysis, we chose different nodes for which the size represents the citation count or the quantity of publications [12, 13].

We conducted bi-clustering analysis on the selected publications and major MeSH terms/MeSH subheadings to explore the hotspots of osteosarcoma and cure. We also constructed a binary matrix with the original documents as columns and the major $\mathrm{MeSH}$ terms/MeSH subheadings as rows for further clustering through BICOMB and gCLUTO version 1.0, Graphical Clustering Toolkit (http://glaros.dtc.umn.edu/gkhome/cluto/ gcluto/download), and the repeated bisection were applied to clustering analysis based on following parameters: I2 and cosine are selected as criterion functions and similarity functions respectively [7]. Moreover, the clustering with different number of clusters was redirected 
to ensure the optimal result of matrix visualization. The existing semantic relationships between major $\mathrm{MeSH}$ terms/MeSH subheadings and the source literature in the clusters were demonstrated through matrix and mountain visualization.

\section{Results}

\section{Publishing trend}

As shown in Fig. 1, 2258 publications (2006 articles and 252 reviews) met our inclusion criteria from 2009 to 2019. The publications related to osteosarcoma and cure continued to increase from 2009 to 2018, but a slight decline occurred in 2019, which may be due to the fact that osteosarcoma has reached a bottleneck period that the prognosis has not improved significantly, and the specific research directions of osteosarcoma was quite unclear which highlights the need for this study to objectively demonstrate the status quo and provide promising direction for future research (overall increase from 106 in 2009 to 303 in 2019, Fig. 2).

\section{Contributions of countries and institutions to global publications}

At least 64 different countries or regions participated in publishing studies on osteosarcoma over the past 10 years (Fig. 3). China (869) was the largest contributor, followed by the United States (520), Italy (172), Japan (137) and Britain (91). Centrality is an important index in evaluating the importance of nodes in a network in that the higher the centrality, the greater the effect of the nodes. We found that the influence of the United States is highly prominent with centrality $=0.44$, followed by the United Kingdom with centrality $=0.26$, which ranks 5 th in the number of publications (Table 1 ). In terms of institutions (a total of 2501), Chinese universities in the top 10 have posted significant papers. In addition, Central South University and the University of Texas MD Anderson Cancer Center have the highest average citation rates of 3.25 and 2.87 , respectively (Table 1). The centrality of most institutions is $<0.1$, indicating a low level of influence and a lack of cooperation over the past decade. Figure 4 reveals that the cooperation between the United States and China was the closest, followed by the cooperation between the United States and the United Kingdom. The figure also suggests an absence of academic exchanges between countries with abundant publications and countries with weak publications.

\section{Journals publishing osteosarcoma and cure}

The 2258 publications covered 772 journals, and the top 10 most popular journals published a total of 373

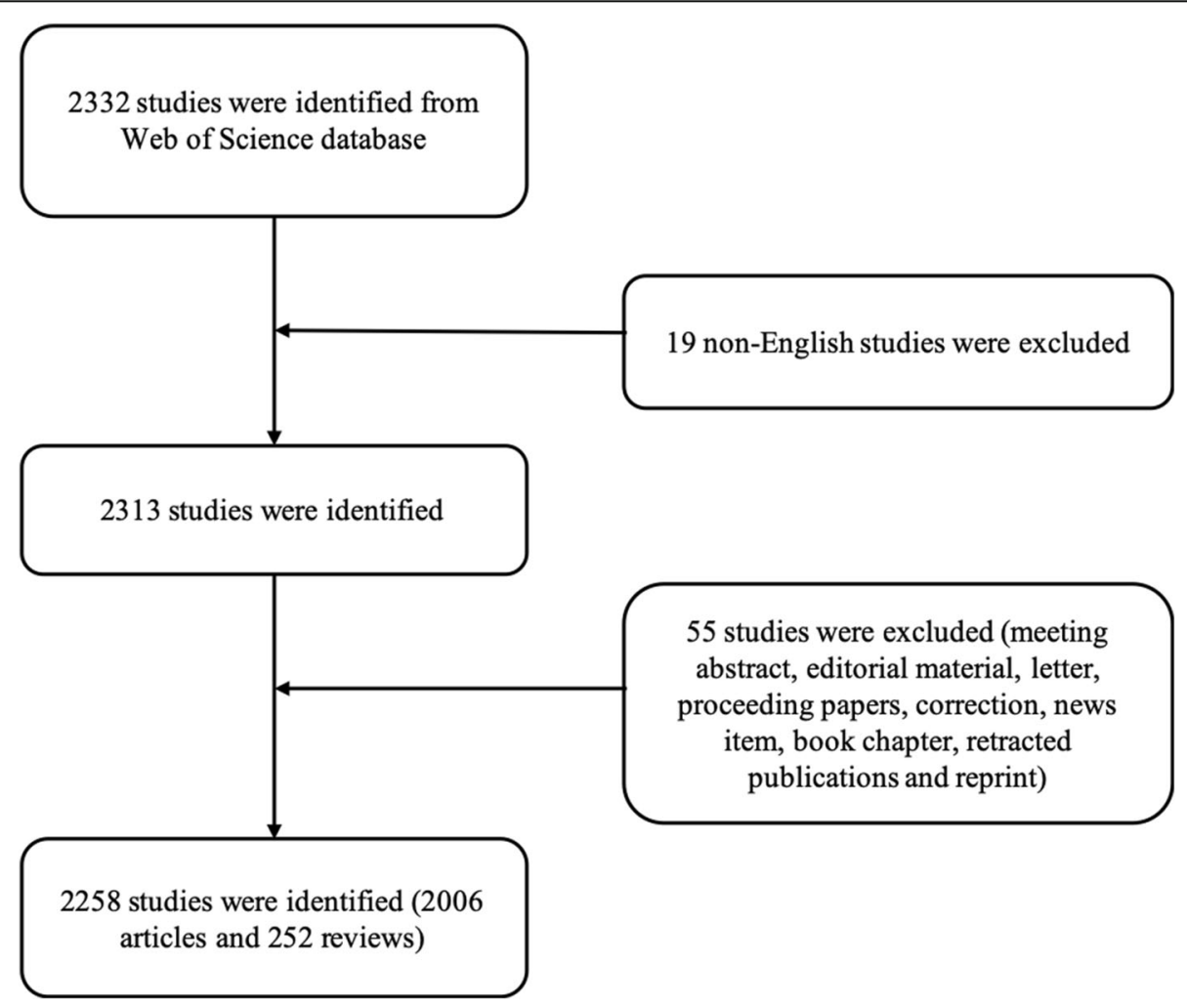

Fig. 1 Flow diagram of the inclusion process 


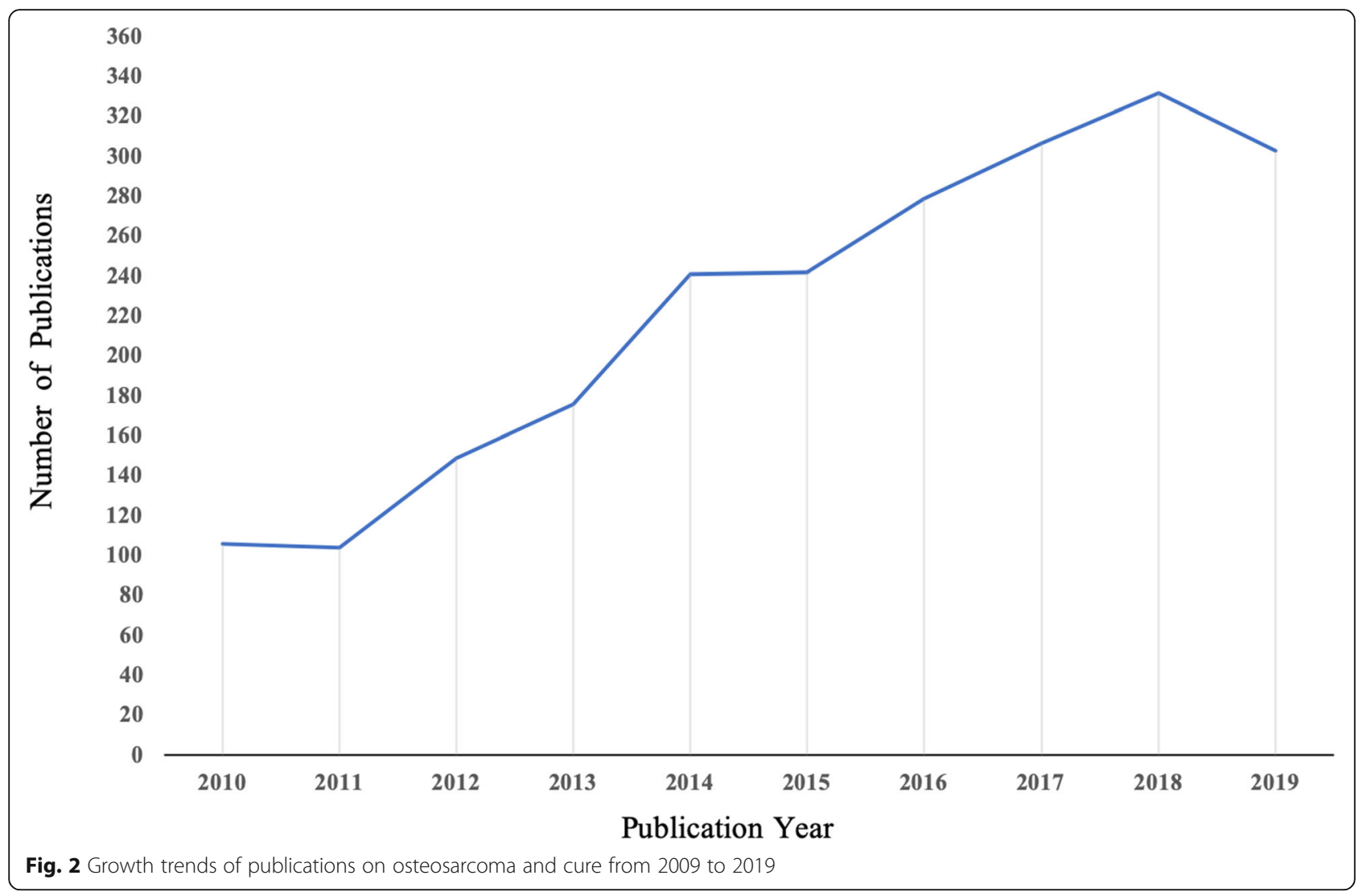

publications (16.52\%). No significant difference was noted in the amount of papers issued by each journal, but the average citation rate of BMC CANCER was the highest at 3.26 (Table 2). Four journals have the characteristic of IF> 3: International Journal of Molecular Sciences (4.183), Scientific Reports (4.011), International Journal of Oncology (3.571) and Oncology Reports (3.041). The above four journals belong to Q1, Q1, Q1 and Q2, respectively, which are based on the JCR 2018 standard.

\section{Contributions of authors to osteosarcoma and cure}

A total of 10,617 authors were filtered out in this study, and the top 10 authors who published the most papers are listed in Table 3. Two scholars, namely, Picci, $\mathrm{P}$ and Gorlick, $\mathrm{R}$, had the highest average citation rates of 7.96 and 6.94, respectively, which demonstrated that they have made great achievements in the study of osteosarcoma and that their publications are of great academic value. The citation information of the authors and the co-cited authors were visualized by CiteSpace as two networks (Fig. 5). Bielack, SS (159) ranked first among the top ten cocitation authors, followed by Bacci, G (156) and Meyers, PA (137) (Table 3). It can be observed that these researchers have become influential experts in the field of osteosarcoma and have reported a substantial amount of research.

\section{Analysis of hotspots}

In our study, we retrieved a total of 9084 major $\mathrm{MeSH}$ terms/MeSH subheadings with a cumulative frequency of 24,485 . We defined terms that appear more than 50 times after evaluation by $\mathrm{H}$ index as extremely frequent terms, and forty-seven terms extracted from publications accounting for $37.61 \%(9209 / 24485)$ are shown in Table 4. The eight clusters (0-7) identified by biclustering were visualized in mountain form to indicate the quantity of extremely frequent major $\mathrm{MeSH}$ terms/ $\mathrm{MeSH}$ subheadings and in matrix form to present the association between the source literature and $\mathrm{MeSH}$ terms/MeSH subheadings (Figs. 6 and 7). To facilitate similar row convergence in a single aggregation cluster, we reset the rows of the initial matrix through gCLUTO and divided each cluster with a black horizontal line (Table 5). Finally, we concluded on the following eight hot items with in-depth interpretation of the corresponding literatures:

New insights into the metastatic pattern of osteosarcoma (cluster 0),

Establishment of new methods for evaluating the sensitivity of chemotherapeutic drugs (cluster 1), 


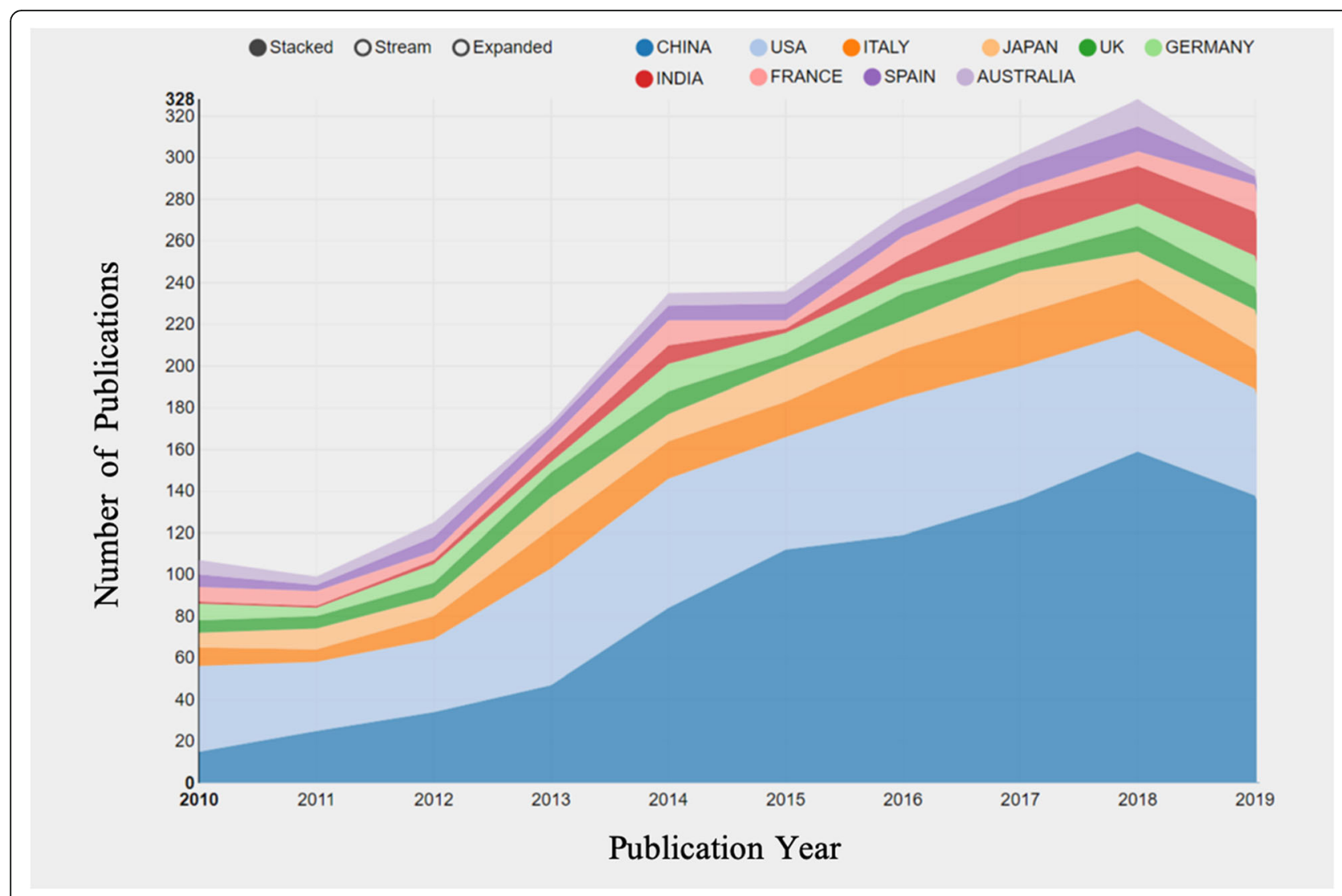

Fig. 3 Growth trends of the top 10 countries on osteosarcoma and cure from 2009 to 2019

Table 1 The top 10 countries and institutions contributing to publications on osteosarcoma and cure

\begin{tabular}{|c|c|c|c|c|c|c|c|c|c|c|c|}
\hline Rank & Country & Articles & Centrality & Institutions & Articles & $\begin{array}{l}\text { Total } \\
\text { number } \\
\text { of } \\
\text { citations }\end{array}$ & Centrality & $\begin{array}{l}\text { Average } \\
\text { number of } \\
\text { citations }\end{array}$ & $\begin{array}{l}\text { Total } \\
\text { number of } \\
\text { first } \\
\text { authors }\end{array}$ & $\begin{array}{l}\text { Total number } \\
\text { of first author } \\
\text { citations }\end{array}$ & $\begin{array}{l}\text { Average } \\
\text { number of first } \\
\text { author citations }\end{array}$ \\
\hline 1 & China & 869 & 0.11 & $\begin{array}{l}\text { Shanghai Jiao } \\
\text { Tong Univ }\end{array}$ & 100 & 233 & 0.12 & 2.33 & 43 & 84 & 1.95 \\
\hline 2 & USA & 520 & 0.44 & Jilin Univ & 99 & 120 & 0.02 & 1.21 & 41 & 66 & 1.61 \\
\hline 3 & Italy & 172 & 0.24 & $\begin{array}{l}\text { Chongqing } \\
\text { Med Univ }\end{array}$ & 86 & 148 & 0.01 & 1.72 & 21 & 27 & 1.29 \\
\hline 4 & Japan & 137 & 0.05 & Cent S Univ & 84 & 273 & 0.02 & 3.25 & 36 & 131 & 3.64 \\
\hline 5 & UK & 91 & 0.26 & $\begin{array}{l}\text { China Med } \\
\text { Univ }\end{array}$ & 83 & 163 & 0.06 & 1.96 & 21 & 26 & 1.24 \\
\hline 6 & Germany & 90 & 0.19 & $\begin{array}{l}\text { Shandong } \\
\text { Univ }\end{array}$ & 71 & 174 & 0.09 & 2.45 & 31 & 55 & 1.77 \\
\hline 7 & India & 89 & 0.05 & $\begin{array}{l}\text { Univ Texas } \\
\text { MD Anderson } \\
\text { Canc Ctr }\end{array}$ & 69 & 198 & 0.06 & 2.87 & 22 & 59 & 2.68 \\
\hline 8 & France & 75 & 0.06 & Zhejiang Univ & 54 & 119 & 0.03 & 2.2 & 29 & 78 & 2.69 \\
\hline 9 & Spain & 70 & 0.05 & Wuhan Univ & 51 & 121 & 0.03 & 2.37 & 20 & 56 & 2.8 \\
\hline 10 & Australia & 61 & 0.07 & $\begin{array}{l}\text { Ohio State } \\
\text { Univ }\end{array}$ & 51 & 106 & 0.17 & 2.08 & 12 & 20 & 1.67 \\
\hline
\end{tabular}




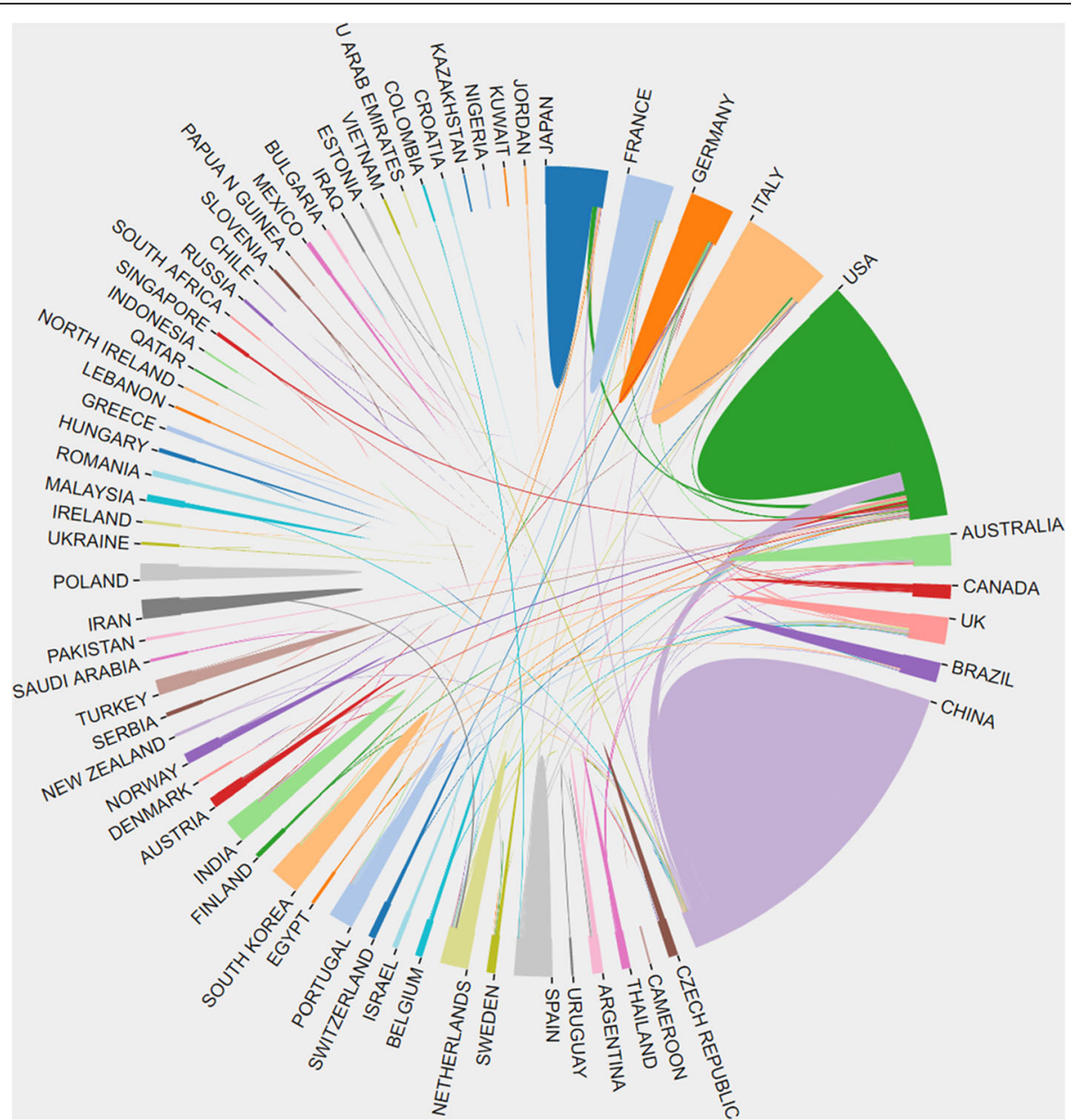

Fig. 4 The cooperation between countries on osteosarcoma and cure

Table 2 The top 10 most active journals with publications on osteosarcoma and cure

\begin{tabular}{|c|c|c|c|c|c|c|c|c|}
\hline Rank & Journal title & $\begin{array}{l}\text { Articles } \\
\text { (N) }\end{array}$ & $\begin{array}{l}\text { Percentage } \\
\text { (N/2258) \% }\end{array}$ & $\begin{array}{l}\text { IF } \\
(2018)\end{array}$ & $\begin{array}{l}\text { Quartile in } \\
\text { category (2018) }\end{array}$ & $\begin{array}{l}\mathrm{H}- \\
\text { index }\end{array}$ & $\begin{array}{l}\text { Total number } \\
\text { of citations }\end{array}$ & $\begin{array}{l}\text { Average number } \\
\text { of citations }\end{array}$ \\
\hline 1 & ONCOTARGET & 59 & 2.61 & 0 & 0 & 91 & 147 & 2.49 \\
\hline 2 & PLOS ONE & 55 & 2.43 & 2.776 & Q1 & 268 & 158 & 2.87 \\
\hline 3 & ONCOLOGY LETTERS & 45 & 1.99 & 1.871 & Q3 & 38 & 82 & 1.82 \\
\hline 4 & ONCOLOGY REPORTS & 40 & 1.77 & 3.041 & Q2 & 84 & 93 & 2.33 \\
\hline 5 & MOLECULAR MEDICINE REPORTS & 37 & 1.64 & 1.851 & Q3 & 43 & 60 & 1.62 \\
\hline 6 & INTERNATIONAL JOURNAL OF ONCOLOGY & 28 & 1.24 & 3.571 & Q1 & 111 & 58 & 2.07 \\
\hline 7 & ANTICANCER RESEARCH & 28 & 1.24 & 1.935 & Q3 & 110 & 38 & 1.36 \\
\hline 8 & BMC CANCER & 27 & 1.20 & 2.933 & Q2 & 111 & 88 & 3.26 \\
\hline 9 & SCIENTIFIC REPORTS & 27 & 1.20 & 4.011 & Q1 & 149 & 37 & 1.37 \\
\hline 10 & $\begin{array}{l}\text { INTERNATIONAL JOURNAL OF MOLECULAR } \\
\text { SCIENCES }\end{array}$ & 27 & 1.20 & 4.183 & Q1 & 114 & 24 & 0.89 \\
\hline
\end{tabular}


Table 3 Each of top 10 authors (most publications and co-cited) on osteosarcoma and cure

\begin{tabular}{|c|c|c|c|c|c|c|c|c|c|c|c|}
\hline Rank & Author & Articles & $\begin{array}{l}\text { Total } \\
\text { number } \\
\text { of } \\
\text { citations }\end{array}$ & $\begin{array}{l}\text { Average } \\
\text { number } \\
\text { of } \\
\text { citations }\end{array}$ & $\begin{array}{l}\text { First } \\
\text { author } \\
\text { counts }\end{array}$ & $\begin{array}{l}\text { First } \\
\text { author } \\
\text { citation } \\
\text { counts }\end{array}$ & $\begin{array}{l}\text { Average } \\
\text { First author } \\
\text { citation } \\
\text { counts }\end{array}$ & $\begin{array}{l}\text { Corresponding } \\
\text { author }\end{array}$ & $\begin{array}{l}\text { Corresponding } \\
\text { author citation } \\
\text { counts }\end{array}$ & $\begin{array}{l}\text { Co-cited } \\
\text { author }\end{array}$ & $\begin{array}{l}\text { Citation } \\
\text { counts }\end{array}$ \\
\hline 1 & Picci, P & 28 & 223 & 7.96 & 1 & 15 & 15 & 1 & 15 & Bielack, SS & 159 \\
\hline 2 & Duan, ZF & 24 & 80 & 3.33 & 3 & 23 & 7.67 & 18 & 58 & Bacci, G & 156 \\
\hline 3 & Hornicek, FJ & 22 & 117 & 5.32 & 0 & 0 & 0 & 1 & 0 & Meyers,PA & 137 \\
\hline 4 & Tsuchiya, H & 22 & 47 & 2.14 & 0 & 0 & 0 & 6 & 27 & Ferrari,S & 129 \\
\hline 5 & Choy, E & 20 & 111 & 5.55 & 0 & 0 & 0 & 0 & 0 & Mirabello,L & 124 \\
\hline 6 & Heymann, D & 20 & 77 & 3.85 & 0 & 0 & 0 & 8 & 47 & Ottaviani,G & 123 \\
\hline 7 & Gorlick, R & 17 & 118 & 6.94 & 3 & 26 & 8.67 & 5 & 64 & Chou,AJ & 114 \\
\hline 8 & Hayashi, K & 16 & 25 & 1.56 & 0 & 0 & 0 & 0 & 0 & Luetke,A & 114 \\
\hline 9 & Miwa, S & 15 & 23 & 1.53 & 5 & 11 & 2.2 & 2 & 2 & Zhang,Y & 93 \\
\hline 10 & Fuchs, B & 14 & 39 & 2.79 & 0 & 0 & 0 & 8 & 24 & Jaffe,N & 89 \\
\hline
\end{tabular}

Alternatives to cytotoxic chemotherapy (cluster 2),

Prognostic markers (cluster 3),

Synergistic therapy of mesenchymal stem cells and drugs (cluster 4),

Reverse chemoresistance in osteosarcoma (cluster 5),

Drug discovery of Chinese herbal extracts to interfere with apoptosis of tumour cells (cluster 6),

Drug discovery of Chinese herbal extracts to interfere with autophagy of tumour cells (cluster 7).

\section{Discussion}

Our statistical and quantitative analysis found a significant improvement in research on osteosarcoma and cure from
2010 to 2019, and an increasing number of orthopaedic and oncology experts focused their insights on this field. Although those studies have been highly extensive, they are relatively chaotic and lack hotspot analysis. Osteosarcoma metastasis, recurrence and multi-drug resistance (MDR) are the three major obstacles in the clinic, we discussed and explained the main 8 clusters obtained from co-word bi-clustering. In addition, we also collated 41 completed clinical trials in osteosarcoma that passed phase II (Table 5) and predicted future research trends by addressing these barriers.

Cluster 0 addresses the new insights on metastatic pattern. The survival rate of osteosarcoma is closely related
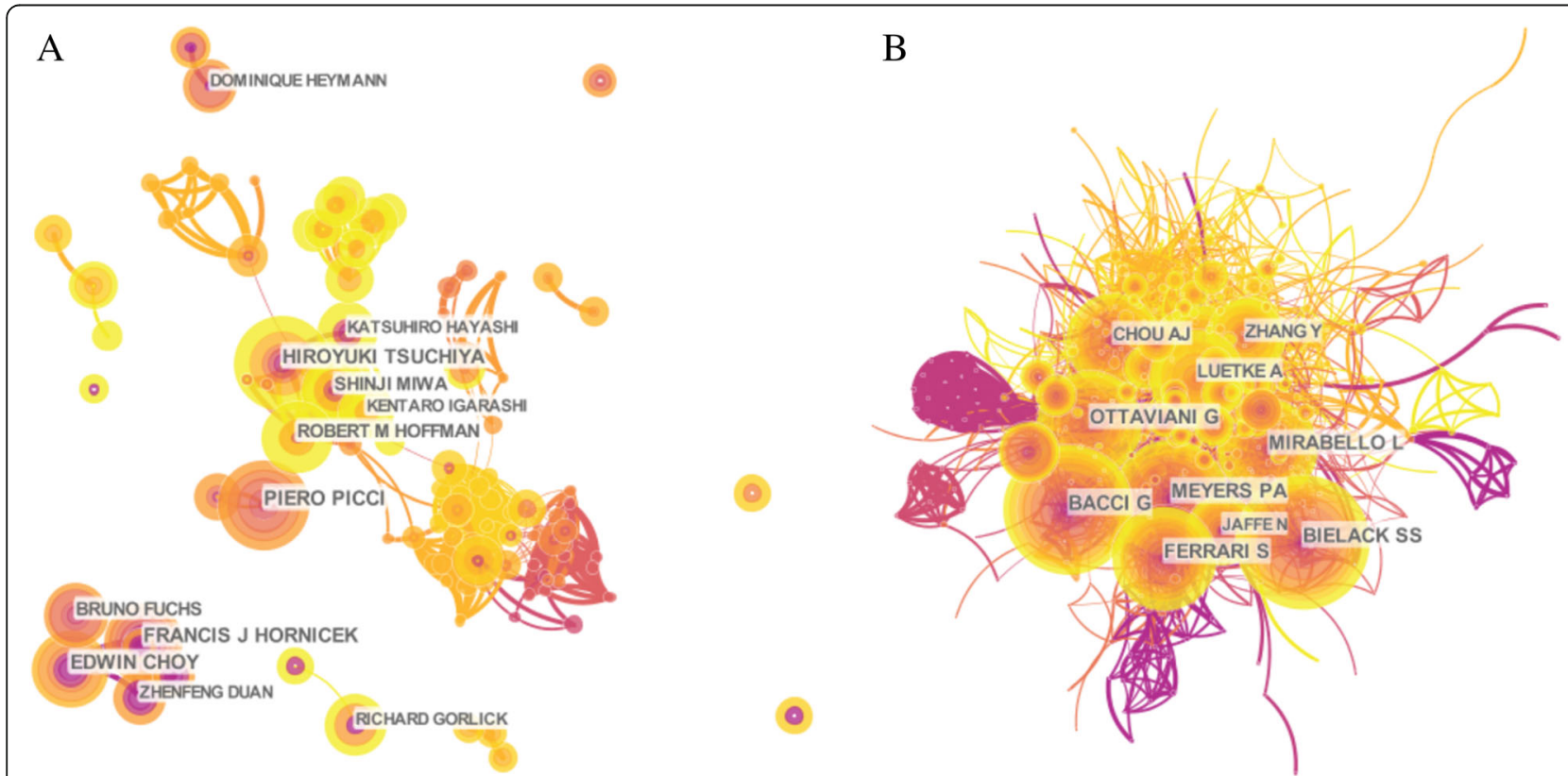

Fig. 5 The distribution of authors engaged in osteosarcoma and cure. The network map of productive authors (a) and the network map of cocited authors (b) 
Table 4 Highly frequent major MeSH terms from the included publications on osteosarcoma and cure $(n=24,485)$

\begin{tabular}{|c|c|c|c|c|}
\hline Rank & Major MeSH terms/ MeSH subheadings & Frequency & Proportion of frequency (\%) & Cumulative percentage (\%) \\
\hline 1 & Osteosarcoma / drug therapy & 984 & 4.0188 & 4.0188 \\
\hline 2 & Bone Neoplasms / drug therapy & 824 & 3.3653 & 7.3841 \\
\hline 3 & Osteosarcoma / pathology & 709 & 2.8957 & 10.2798 \\
\hline 4 & Bone Neoplasms / pathology & 513 & 2.0952 & 12.3749 \\
\hline 5 & Osteosarcoma / genetics & 505 & 2.0625 & 14.4374 \\
\hline 6 & Osteosarcoma / metabolism & 457 & 1.8664 & 16.3039 \\
\hline 7 & Antineoplastic Agents / pharmacology & 360 & 1.4703 & 17.7741 \\
\hline 8 & Bone Neoplasms / genetics & 352 & 1.4376 & 19.2118 \\
\hline 9 & Bone Neoplasms / metabolism & 306 & 1.2497 & 20.4615 \\
\hline 10 & Apoptosis / drug effects & 292 & 1.1926 & 21.6541 \\
\hline 11 & Sarcoma, Ewing / drug therapy & 246 & 1.0047 & 22.6588 \\
\hline 12 & Antineoplastic Combined Chemotherapy / therapeutic use & 186 & 0.7596 & 23.4184 \\
\hline 13 & Osteosarcoma / veterinary & 176 & 0.7188 & 24.1372 \\
\hline 14 & Sarcoma, Ewing / pathology & 171 & 0.6984 & 24.8356 \\
\hline 15 & MicroRNAs / genetics & 166 & 0.678 & 25.5136 \\
\hline 16 & Antineoplastic Agents / therapeutic use & 165 & 0.6739 & 26.1875 \\
\hline 17 & Bone Neoplasms / therapy & 150 & 0.6126 & 26.8001 \\
\hline 18 & Osteosarcoma / therapy & 149 & 0.6085 & 27.4086 \\
\hline 19 & Gene Expression Regulation, Neoplastic & 141 & 0.5759 & 27.9845 \\
\hline 20 & Cell Proliferation / drug effects & 137 & 0.5595 & 28.544 \\
\hline 21 & Osteosarcoma / surgery & 137 & 0.5595 & 29.1035 \\
\hline 22 & Bone Neoplasms / surgery & 135 & 0.5514 & 29.6549 \\
\hline 23 & Osteosarcoma / diagnosis & 116 & 0.4738 & 30.1287 \\
\hline 24 & Bone Neoplasms / diagnosis & 111 & 0.4533 & 30.582 \\
\hline 25 & Bone Neoplasms / veterinary & 105 & 0.4288 & 31.0108 \\
\hline 26 & Lung Neoplasms / secondary & 99 & 0.4043 & 31.4152 \\
\hline 27 & Sarcoma, Ewing / genetics & 98 & 0.4002 & 31.8154 \\
\hline 28 & Osteosarcoma / diagnostic imaging & 98 & 0.4002 & 32.2156 \\
\hline 29 & Signal Transduction / drug effects & 97 & 0.3962 & 32.6118 \\
\hline 30 & Bone Neoplasms / diagnostic imaging & 87 & 0.3553 & 32.9671 \\
\hline 31 & Sarcoma, Ewing / diagnosis & 85 & 0.3472 & 33.3143 \\
\hline 32 & Sarcoma, Ewing / therapy & 82 & 0.3349 & 33.6492 \\
\hline 33 & Sarcoma, Ewing / metabolism & 78 & 0.3186 & 33.9677 \\
\hline 34 & Drug Resistance, Neoplasm / genetics & 77 & 0.3145 & 34.2822 \\
\hline 35 & Osteosarcoma / secondary & 73 & 0.2981 & 34.5804 \\
\hline 36 & Antineoplastic Agents, Phytogenic / pharmacology & 72 & 0.2941 & 34.8744 \\
\hline 37 & Cisplatin / pharmacology & 72 & 0.2941 & 35.1685 \\
\hline 38 & Bone Neoplasms / mortality & 71 & 0.29 & 35.4584 \\
\hline 39 & MicroRNAs / metabolism & 68 & 0.2777 & 35.7362 \\
\hline 40 & Doxorubicin / pharmacology & 62 & 0.2532 & 35.9894 \\
\hline 41 & Osteosarcoma / mortality & 62 & 0.2532 & 36.2426 \\
\hline 42 & Drug Resistance, Neoplasm & 62 & 0.2532 & 36.4958 \\
\hline 43 & Sarcoma, Ewing / surgery & 62 & 0.2532 & 36.749 \\
\hline 44 & Autophagy / drug effects & 54 & 0.2205 & 36.9696 \\
\hline 45 & Biomarkers, Tumor / genetics & 53 & 0.2165 & 37.186 \\
\hline 46 & Osteosarcoma / enzymology & 53 & 0.2165 & 37.4025 \\
\hline 47 & Gene Expression Regulation, Neoplastic / drug effects & 50 & 0.2042 & 37.6067 \\
\hline
\end{tabular}




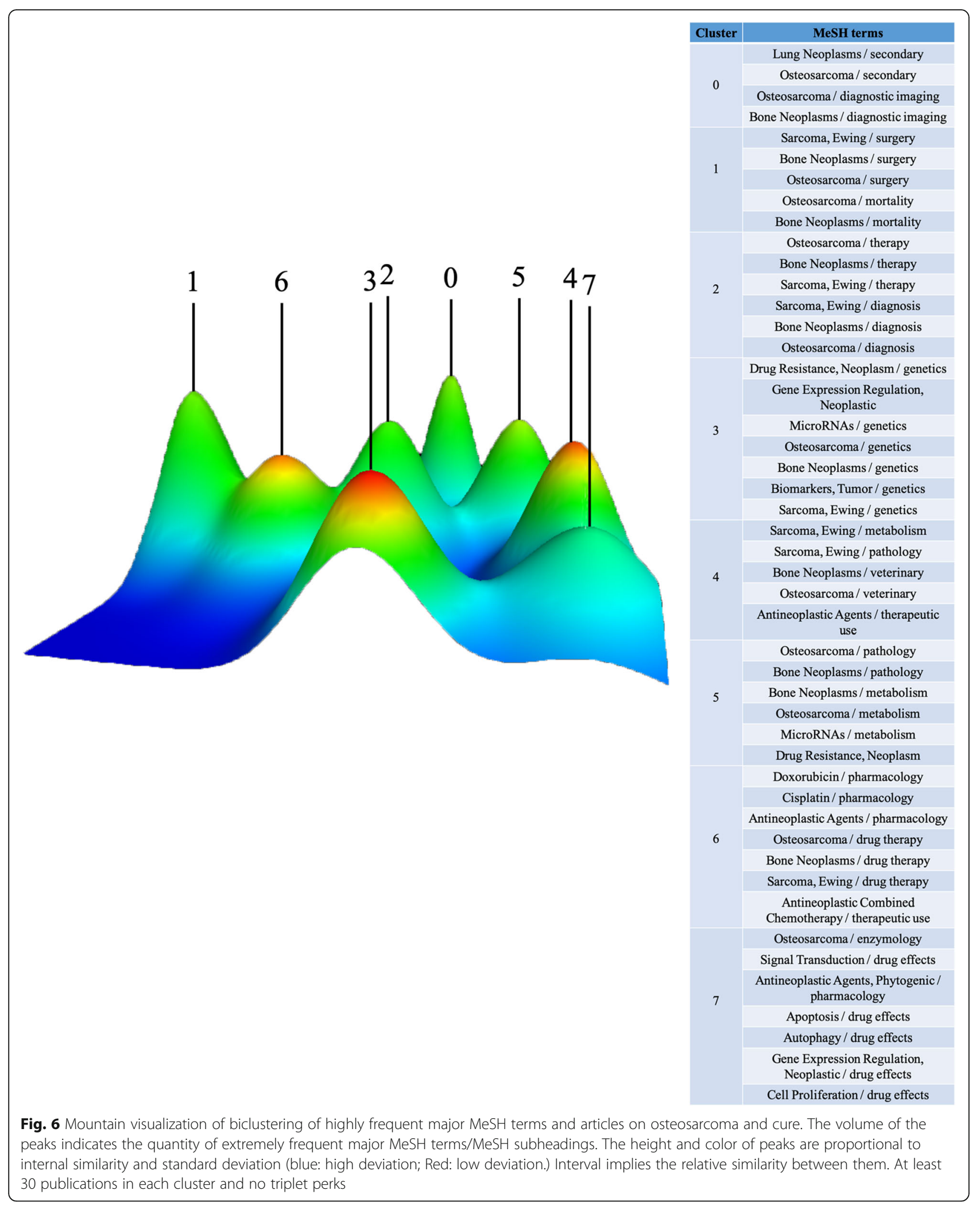



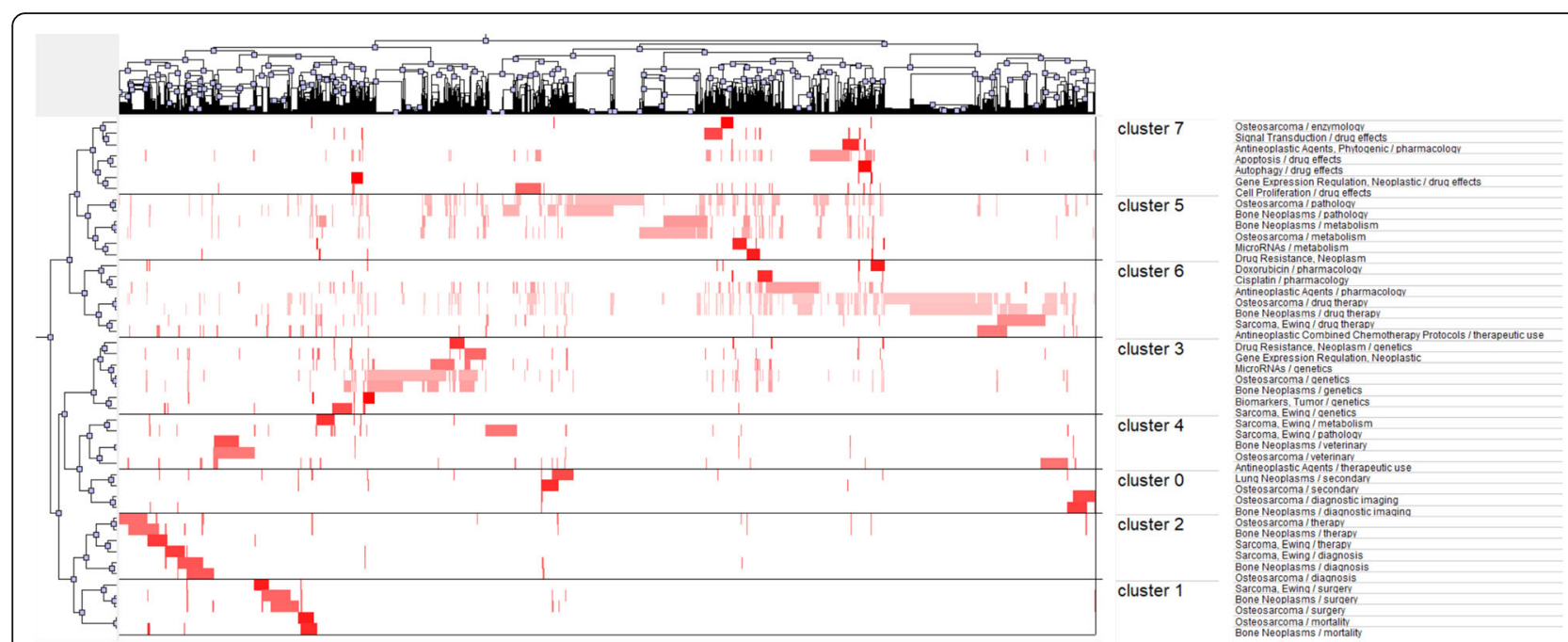

Fig. 7 Visualized matrix of biclustering of highly frequent major MeSH terms and PubMed Unique Identifiers (PMIDs) of articles on osteosarcoma and cure. The cluster at the top indicates the literature, and the left represents extremely frequent major MeSH terms/MeSH subheadings. The color of the grid is relative to the frequency of it. (dark red is significant, white is close to non-significant)

to tumour metastasis in that $15-20 \%$ of patients were diagnosed with distant metastatic lesions at their first visit [14]. Previous studies have recognized that the lung is the most sensitive site, but the occurrence of abdominal metastasis reveals an unusual pattern in which osteosarcoma is more prone to occur in soft tissue [15]. Changes in the tumour microenvironment and extracellular matrix composition seriously affect osteosarcoma metastasis, e.g., the "seed and soil hypothesis". The rich bone microenvironment constitutes a fertile "soil" that favours the growth of both primary and metastatic tumoural "seeds", and the host "soil" is transferred to undergo biological changes in advance to adapt to the invasion of "seeds" [16]. Clinicians should be aware of the development of metastatic patterns in patients with osteosarcoma, and the exploration of microenvironmental tumour genetic disorders between primary occurrence and metastasis is the subject of future basic research.

Cluster 1 investigates new methods for evaluating the sensitivity of chemotherapeutic drugs. The sensitivity of osteosarcoma to chemotherapeutics drugs plays a critical role in the choice of operation and in tumour recurrence. Current standard treatments for osteosarcoma include neoadjuvant multidrug chemotherapy, growth factor support, surgery (amputation or limb salvage), and radiotherapy [17]. It is known that limb salvage surgery still has many complications, such as local recurrence, and amputees are more likely to suffer from metastasis and a lower survival rate and that all of those complications are attributed to insufficient chemotherapy [18]. Hence, a new reliable method for determining the effectiveness of chemotherapeutic drugs prior to surgery is expected to aid surgeons in choosing surgical tactics, such as radiological functional imaging (dynamic contrast enhanced magnetic resonance imaging, magnetic resonance diffusion weighted and deoxyglucose positron emission tomography). These approaches were applied to clinical studies (Table 5; No. 9, 17).

Cluster 2 involves alternatives to cytotoxic chemotherapy. Currently, no effective alternative therapy is available to treat osteosarcoma after failure of traditional chemotherapy and surgery. Based on the literature in the past 10 years, we found that researchers at home and abroad are actively exploring strategies to replace systemic chemotherapy for osteosarcoma: (1) immunotherapy, including active (cancer vaccine, adoptive T-cell transfer (Table 5; No. 36), checkpoint inhibitor (programmed cell death-ligand 1, T-cell immunoglobulin, mucin-domain containing-3, Indoleamine 2,3-di-oxygenase) and cytokines) and passive (monoclonal antibodies and adjuvants (Table 5; No. 11, 15, 22, 23)) approaches [19]; (2) local chemotherapy in which implantable drug delivery systems with anticancer drugs and bone substitutes as carriers can protect drugs from rapid metabolism in circulation and ensure the objective therapeutic effect of low dose therapies such as cyclodextrins, polylactic-co-glycolic acid and cyclodextrins [20], and nanoparticle albumin binding paclitaxel could increase the drug concentration in tumour cells (Table 5; No. 21); (3) radiotherapy, including stereotactic radiosurgery, carbon-ion radiotherapy, etc. [21, 22]; (4) genetic engineering, e.g., biological genetic engineering-edited miRNAs that target RNA molecules [23]; (5) stem cell therapy (Table 5; No. 13, 37); and (6) novel alternative therapeutic drugs originating from Chinese herbal extracts. These two points are discussed in detail later on. 
Table 5 The representative completed clinical trials about osteosarcoma

\begin{tabular}{|c|c|c|c|}
\hline No. & Study Title & Conditions & Interventions \\
\hline 1 & $\begin{array}{l}\text { Investigation of [6R] 5,10-methylenetetrahydrofolate as Rescue } \\
\text { Therapy for Osteosarcoma Patients Treated with HDMTX }\end{array}$ & Osteosarcoma & $\begin{array}{l}\text { Drug: Calcium Folinate and [6R] } \\
\text { 5,10-methylenetetrahydrofolate }\end{array}$ \\
\hline 2 & $\begin{array}{l}\text { Phase II Study of Chemotherapy and Pamidronate for the } \\
\text { Treatment of Newly Diagnosed Osteosarcoma }\end{array}$ & Osteosarcoma & $\begin{array}{l}\text { Drug: Cisplatin, Doxorubicin and } \\
\text { Methotrexate }\end{array}$ \\
\hline 3 & $\begin{array}{l}\text { Glembatumumab Vedotin in Treating Patients with Recurrent } \\
\text { or Refractory Osteosarcoma }\end{array}$ & $\begin{array}{l}\text { Recurrent } \\
\text { Osteosarcoma }\end{array}$ & $\begin{array}{l}\text { Drug: Glembatumumab Vedotin } \\
\text { Other: Laboratory Biomarker Analysis } \\
\text { And Pharmacological Study }\end{array}$ \\
\hline 4 & $\begin{array}{l}\text { Eribulin Mesylate in Treating Patients with Recurrent or } \\
\text { Refractory Osteosarcoma }\end{array}$ & $\begin{array}{l}\text { Recurrent } \\
\text { Osteosarcoma }\end{array}$ & $\begin{array}{l}\text { Drug: Eribulin Mesylate } \\
\text { Other: Pharmacological Study }\end{array}$ \\
\hline 5 & Chemotherapy for Patients with Osteosarcoma & Osteosarcoma & Drug: Pemetrexed \\
\hline 6 & $\begin{array}{l}\text { Inhalation SLIT Cisplatin (Liposomal) for the Treatment } \\
\text { of Osteosarcoma Metastatic to the Lung }\end{array}$ & $\begin{array}{l}\text { Osteosarcoma } \\
\text { Metastatic }\end{array}$ & Drug: Cisplatin liposomal \\
\hline 7 & $\begin{array}{l}\text { Preventing Nephrotoxicity and Ototoxicity from } \\
\text { Osteosarcoma Therapy }\end{array}$ & Osteosarcoma & $\begin{array}{l}\text { Drug: Pantoprazole and High-dose } \\
\text { methotrexate infusion duration }\end{array}$ \\
\hline 8 & $\begin{array}{l}\text { Inhaled Sargramostim in Treating Patients with First } \\
\text { Pulmonary (Lung) Recurrence of Osteosarcoma }\end{array}$ & $\begin{array}{l}\text { Metastatic Cancer } \\
\text { Sarcoma }\end{array}$ & $\begin{array}{l}\text { Biological: sargramostim } \\
\text { Procedure: conventional surgery }\end{array}$ \\
\hline 9 & $\begin{array}{l}\text { Differentiation of Bone Sarcomas and Osteomyelitis } \\
\text { with Ferumoxytol-Enhanced MRI }\end{array}$ & $\begin{array}{l}\text { Bone Cancer } \\
\text { Osteosarcoma }\end{array}$ & $\begin{array}{l}\text { Drug: Feraheme } \\
\text { Procedure: Magnetic Resonance } \\
\text { Imaging (MRI) scan }\end{array}$ \\
\hline 10 & Dacarbazine for Metastatic Soft Tissue and Bone Sarcoma & Sarcoma & Drug: Dacarbazine \\
\hline 11 & $\begin{array}{l}\text { A Study of Bevacizumab in Combination with } \\
\text { Chemotherapy for Treatment of Osteosarcoma }\end{array}$ & Osteosarcoma & $\begin{array}{l}\text { Biological: Bevacizumab } \\
\text { Drug: Cisplatin, Doxorubicin, } \\
\text { Methotrexate, Ifosfamide, etoposide } \\
\text { Procedure: Surgery } \\
\text { Radiation: Radiotherapy }\end{array}$ \\
\hline 12 & $\begin{array}{l}\text { A Phase II Study of Oral Cyclophosphamide and } \\
\text { Sirolimus (OCR) in Advanced Sarcoma }\end{array}$ & Osteosarcoma & $\begin{array}{l}\text { Drug: Cyclophosphamide and } \\
\text { Sirolimus }\end{array}$ \\
\hline 13 & $\begin{array}{l}\text { Samarium Sm } 153 \text { and Stem Cell Transplant } \\
\text { Followed by Radiation Therapy Patients with } \\
\text { Osteosarcoma }\end{array}$ & Sarcoma & $\begin{array}{l}\text { Biological: filgrastim } \\
\text { Drug: ifosfamide } \\
\text { Procedure: peripheral blood stem cell } \\
\text { transplantation } \\
\text { Radiation: Sm-EDTMP (low dose) and } \\
\text { Sm-EDTMP (higher dose) }\end{array}$ \\
\hline 14 & $\begin{array}{l}\text { Gemcitabine and Docetaxel in Treating Patients } \\
\text { with Recurrent Osteosarcoma (Closed to Accrual } \\
\text { as of } 12 / 21 / 06 \text { ) or Ewing's Sarcoma or Unresectable } \\
\text { or Locally Recurrent Chondrosarcoma }\end{array}$ & Sarcoma & $\begin{array}{l}\text { Biological: filgrastim and pegfilgrastim } \\
\text { Drug: docetaxel and gemcitabine } \\
\text { hydrochloride } \\
\text { Genetic: microarray analysis } \\
\text { Other: laboratory biomarker analysis } \\
\text { and pharmacokinetic study }\end{array}$ \\
\hline 15 & $\begin{array}{l}\text { Temsirolimus and Cixutumumab in Treating } \\
\text { Patients with Locally Advanced, Metastatic, or } \\
\text { Recurrent Soft Tissue Sarcoma or Bone Sarcoma } \\
\text { Metastatic Osteosarcoma }\end{array}$ & $\begin{array}{l}\text { Recurrent } \\
\text { Osteosarcoma }\end{array}$ & $\begin{array}{l}\text { Biological: Cixutumumab } \\
\text { Other: Laboratory Biomarker Analysis } \\
\text { Drug: Temsirolimus }\end{array}$ \\
\hline 16 & $\begin{array}{l}\text { Therapeutic Angiotensin-(1-7) in Treating Patients } \\
\text { with Metastatic Sarcoma That Cannot Be Removed } \\
\text { by Surgery }\end{array}$ & $\begin{array}{l}\text { Bone Cancer } \\
\text { Metastatic } \\
\text { Osteosarcoma }\end{array}$ & $\begin{array}{l}\text { Drug: therapeutic angiotensin- }(1-7) \\
\text { Other: laboratory biomarker analysis }\end{array}$ \\
\hline 17 & $\begin{array}{l}\text { Sorafenib in Treating Patients with Soft Tissue Sarcomas } \\
\text { (Extremity Sarcoma Closed to Entry as of 5/30/07) }\end{array}$ & $\begin{array}{l}\text { Metastatic } \\
\text { Osteosarcoma } \\
\text { Recurrent } \\
\text { Osteosarcoma }\end{array}$ & $\begin{array}{l}\text { Drug: sorafenib tosylate } \\
\text { Procedure: therapeutic conventional } \\
\text { surgery, computed tomography and dynamic } \\
\text { contrast-enhanced magnetic resonance imaging } \\
\text { Other: laboratory biomarker analysis and } \\
\text { pharmacological study }\end{array}$ \\
\hline 18 & $\begin{array}{l}\text { Safety and Efficacy Study of Torisel and Liposomal } \\
\text { Doxorubicin for Patients with Recurrent Sarcoma }\end{array}$ & Sarcoma & Drug: temsirolimus plus liposomal doxorubicin \\
\hline 19 & A Study of Pemetrexed in Children with Recurrent Cancer & Osteosarcoma & Drug: pemetrexed \\
\hline 20 & $\begin{array}{l}\text { Vismodegib and Gamma-Secretase/Notch Signalling } \\
\text { Pathway Inhibitor RO4929097 in Treating Patients with } \\
\text { Advanced or Metastatic Sarcoma Metastatic Osteosarcoma }\end{array}$ & $\begin{array}{l}\text { Recurrent } \\
\text { Osteosarcoma }\end{array}$ & $\begin{array}{l}\text { Drug: Gamma-Secretase Inhibitor RO4929097 } \\
\text { and Vismodegib } \\
\text { Other: Laboratory Biomarker Analysis and } \\
\text { Pharmacological Study }\end{array}$ \\
\hline 21 & $\begin{array}{l}\text { Study to Find a Safe Dose and Show Early Clinical Activity } \\
\text { of Weekly Nab-paclitaxel in Pediatric Patients with Recurrent/ } \\
\text { Refractory Solid Tumors }\end{array}$ & $\begin{array}{l}\text { Osteogenic } \\
\text { Sarcoma }\end{array}$ & Drug: nab-paclitaxel \\
\hline 22 & $\begin{array}{l}\text { Cixutumumab and Temsirolimus in Treating Younger Patients } \\
\text { with Recurrent or Refractory Sarcoma }\end{array}$ & $\begin{array}{l}\text { Recurrent } \\
\text { Osteosarcoma }\end{array}$ & $\begin{array}{l}\text { Biological: Cixutumumab } \\
\text { Other: Laboratory Biomarker Analysis } \\
\text { Drug: Temsirolimus }\end{array}$ \\
\hline
\end{tabular}


Table 5 The representative completed clinical trials about osteosarcoma (Continued)

\begin{tabular}{|c|c|c|c|}
\hline No. & Study Title & Conditions & Interventions \\
\hline 23 & $\begin{array}{l}\text { Cixutumumab in Treating Patients with Relapsed or Refractory } \\
\text { Solid Tumors }\end{array}$ & $\begin{array}{l}\text { Recurrent } \\
\text { Osteosarcoma }\end{array}$ & $\begin{array}{l}\text { Biological: cixutumumab } \\
\text { Other: laboratory biomarker analysis }\end{array}$ \\
\hline 24 & $\begin{array}{l}\text { Alisertib in Treating Young Patients with Recurrent or } \\
\text { Refractory Solid Tumors or Leukemia }\end{array}$ & $\begin{array}{l}\text { Recurrent } \\
\text { Osteosarcoma }\end{array}$ & $\begin{array}{l}\text { Drug: Alisertib } \\
\text { Other: Laboratory Biomarker Analysis } \\
\text { and Pharmacological Study }\end{array}$ \\
\hline 25 & $\begin{array}{l}\text { Depsipeptide (Romidepsin) in Treating Patients with } \\
\text { Metastatic or Unresectable Soft Tissue Sarcoma }\end{array}$ & $\begin{array}{l}\text { Adult Extraskeletal } \\
\text { Osteosarcoma }\end{array}$ & Drug: romidepsin \\
\hline 26 & Eurosarc Trial of Linsitinib in Advanced Ewing Sarcoma & $\begin{array}{l}\text { Relapsed Ewing } \\
\text { Sarcoma } \\
\text { Refractory Ewing } \\
\text { Sarcoma }\end{array}$ & Drug: Linsitinib \\
\hline 27 & Olaparib in Adults with Recurrent/Metastatic Ewing's Sarcoma & Ewing's Sarcoma & Drug: Olaparib \\
\hline 28 & $\begin{array}{l}\text { Cytarabine in Treating Young Patients with Recurrent or } \\
\text { Refractory Ewing's Sarcoma }\end{array}$ & Sarcoma & Drug: cytarabine \\
\hline 29 & $\begin{array}{l}\text { Vinblastine, Celecoxib, and Combination Chemotherapy in } \\
\text { Treating Patients with Newly-Diagnosed Metastatic Ewing's } \\
\text { Sarcoma Family of Tumors }\end{array}$ & Sarcoma & $\begin{array}{l}\text { Drug: celecoxib, cyclophosphamide, } \\
\text { doxorubicin hydrochloride, etoposide, } \\
\text { ifosfamide, vinblastine sulfate, vincristine } \\
\text { sulfate, MESNA and Filgrastim } \\
\text { Procedure: conventional surgery } \\
\text { Radiation: radiation therapy }\end{array}$ \\
\hline 30 & $\begin{array}{l}\text { Sunitinib in Treating Patients with Metastatic, Locally Advanced, } \\
\text { or Locally Recurrent Sarcomas }\end{array}$ & Sarcoma & Drug: sunitinib malate \\
\hline 31 & $\begin{array}{l}\text { Vincristine Sulfate, Topotecan Hydrochloride, and } \\
\text { Cyclophosphamide with or Without Bevacizumab in Treating } \\
\text { Young Patients with Refractory or First Recurrent Extracranial } \\
\text { Ewing Sarcoma }\end{array}$ & $\begin{array}{l}\text { Ewing Sarcoma of } \\
\text { Bone }\end{array}$ & $\begin{array}{l}\text { Drug: topotecan hydrochloride, } \\
\text { vincristine sulfate and cyclophosphamide } \\
\text { Biological: bevacizumab }\end{array}$ \\
\hline 32 & $\begin{array}{l}\text { Cyclophosphamide, Topotecan, and Bevacizumab (CTB) in } \\
\text { Patients with Relapsed/Refractory Ewing's Sarcoma and } \\
\text { Neuroblastoma }\end{array}$ & $\begin{array}{l}\text { Neuroblastoma } \\
\text { Sarcoma }\end{array}$ & $\begin{array}{l}\text { Drug: Cyclophosphamide, Topotecan, } \\
\text { and Bevacizumab }\end{array}$ \\
\hline 33 & $\begin{array}{l}\text { A Five-Tier, Open-Label Study of IMC-A12 in Advanced } \\
\text { Sarcoma Ewing's }\end{array}$ & Sarcoma & Biological: IMC-A12 (cixutumumab) \\
\hline 34 & Trial of Dasatinib in Advanced Sarcomas & Sarcoma, Ewing's & Drug: Dasatinib \\
\hline 35 & $\begin{array}{l}\text { Trabectedin in Treating Young Patients with Recurrent or } \\
\text { Refractory Soft Tissue Sarcoma or Ewing's Family of Tumors }\end{array}$ & $\begin{array}{l}\text { Recurrent Ewing } \\
\text { Sarcoma }\end{array}$ & $\begin{array}{l}\text { Drug: trabectedin } \\
\text { Other: pharmacological study }\end{array}$ \\
\hline 36 & $\begin{array}{l}\text { A Pilot Study of Autologous T-Cell Transplantation with Vaccine } \\
\text { Driven Expansion of Anti-Tumor Effectors After Cytoreductive } \\
\text { Therapy in Metastatic Pediatric Sarcomas }\end{array}$ & $\begin{array}{l}\text { Ewing's Sarcoma } \\
\text { Rhabdomyosarcoma }\end{array}$ & $\begin{array}{l}\text { Biological: therapeutic autologous } \\
\text { dendritic cells } \\
\text { Drug: indinavir sulfate } \\
\text { Procedure: peripheral blood stem cell } \\
\text { transplantation }\end{array}$ \\
\hline 37 & $\begin{array}{l}\text { Combination Chemotherapy and Peripheral Stem Cell } \\
\text { Transplantation in Treating Patients with Sarcoma }\end{array}$ & Sarcoma & $\begin{array}{l}\text { Biological: filgrastim } \\
\text { Drug: cisplatin, doxorubicin hydrochloride, } \\
\text { ifosfamide and melphalan } \\
\text { Procedure: peripheral blood stem cell } \\
\text { transplantation }\end{array}$ \\
\hline 38 & $\begin{array}{l}\text { Study Of CP- } 751,871 \text { In Patients with Ewing's Sarcoma } \\
\text { Family of Tumors }\end{array}$ & Ewing's Sarcoma & Drug: CP-751,871 \\
\hline 39 & $\begin{array}{l}\text { Arsenic Trioxide in Treating Patients with Advanced } \\
\text { Neuroblastoma or Other Childhood Solid Tumors }\end{array}$ & Sarcoma & Drug: arsenic trioxide \\
\hline 40 & $\begin{array}{l}\text { Plerixafor After Radiation Therapy and Temozolomide in } \\
\text { Treating Patients with Newly Diagnosed High Grade Glioma }\end{array}$ & $\begin{array}{l}\text { Adult } \\
\text { Medulloblastoma }\end{array}$ & $\begin{array}{l}\text { Radiation: radiation therapy } \\
\text { Drug: temozolomide and plerixafor } \\
\text { Other: laboratory biomarker analysis } \\
\text { and pharmacological study }\end{array}$ \\
\hline 41 & $\begin{array}{l}\text { Therapy to Treat Ewing's Sarcoma, Rhabdomyosarcoma } \\
\text { or Neuroblastoma }\end{array}$ & Sarcoma & $\begin{array}{l}\text { Drug: Tumor Purged/CD25 Depleted Lymphocytes and rhlL-7 } \\
\text { Biological: Tumor Purged/CD25 Depleted Lymphocytes with Tumor Lysate/KLH } \\
\text { Pulsed Dendritic Cell Vaccine and Tumor Lysate/KLH Pulsed Dendritic Cell } \\
\text { Vaccine }\end{array}$ \\
\hline
\end{tabular}

In terms of the future, with the rapid development of biotechnology, current research is focusing on alternative methods of impairing osteosarcoma outside of cytotoxic chemotherapy.

Cluster 3 explores new prognostic markers for osteosarcoma. The urgent need exists for early diagnosis, and it is beneficial to adopt a better therapeutic schedule. The existing clinical trials focus on that topic (Table 5). Studies have shown that a variety of miRNAs in osteosarcoma tissues or blood samples have been altered and are closely associated with poor prognosis of either deaths or events [24], such as high expression of miRNA 
210, 17-92 cluster, 128, 9, 214, 542-5p, 130b, 130a, and $199 \mathrm{~b}-5 \mathrm{p}$ and low expression of miRNA 132, 145, 382, 133a, 26a, 340, 20a, 92a, 143, 451, 144, 22, 195, 124, 449a, 99a, and 224 [25]. In addition, large-scale prospective studies are expected to elucidate the prognostic role of miRNAs in osteosarcoma, and the role of these miRNAs in assessing tumour progression and therapeutic responses will depend on additional clinical trials.

Cluster 4 is related to synergistic therapy of mesenchymal stem cells (MSCs) and drugs. Tumour cells in osteosarcoma are similar to osteoblasts in that they present osteoblastic differentiation and produce malignant osteoid, not only in osteoblastic areas but also in chondroblast or fibroblast areas, which suggests that osteosarcoma cells might originate from MSCs. We know that MSCs are highly prone to tumour stroma and can promote MDR by increasing the expression of multi-drug resistance genes or by paracrine pathways (STAT3, IL-6, IL-8, etc.) [26]. By taking advantage of this knowledge, we can load MSCs with therapeutic drugs to exert their anticancer capacity more effectively. It has been reported that rhBMP-2 and MSCs combined with conventional antitumour therapy might be an efficient therapeutic strategy against osteosarcoma [27]. However, conventional chemicals as the carriers in MSCs might disrupt the normal function of MSCs and cause drug delivery failure. Duchi found that photodynamic therapy, in which MSCs are stimulated by light activation to release toxic drugs that kill the surrounding tumour cells and induce their own death, might be a good option [28]. Furthermore, MSCs transfected with adenovirus carrying the osteoprotegerin gene inhibited osteosarcoma growth and bone destruction [29]. In addition to cytotoxic drugs and viral vectors, antiangiogenic agents and immunostimulants can also be delivered to tumour lesions by MSCs [30]. Existing clinical trials explored stem cell transplantation to treat sarcomas (Table 5, No. 13, 37). In the next few decades, MSCs are expected to certainly display their advantages in carrying targeted drugs or antitumour genes for osteosarcoma treatment and are an exploration direction for researchers.

Cluster 5 focuses on reverse chemoresistance. Studies over the past 10 years reflect that chemotherapy for osteosarcoma has entered a bottleneck period. Even with increasing the dose, the types of drugs combined with chemotherapy and alteration of the delivery pathway still cannot improve the 5-year survival rate. Although MAP (methotrexate, doxorubicin and cisplatin) has become the preferred clinical treatment regimen, the problem of MDR still exists due to the following mechanisms: the reduction of effective intracellular accumulation, the abnormal content or activity of drug metabolism enzymes, and the genomic complexity and tumour heterogeneity of osteosarcoma [31]. Enhanced cell detoxification, DNA damage repair, apoptosis inhibition and autophagyrelated chemoresistance also contributed to the emergence of osteosarcoma MDR, which is the main reason for the low survival rate. Targeted and precise individual therapy is the key step in overcoming MDR [32]. Exploration of MDR-related molecules such as proteins, enzymes, miRNA, lncRNA, circular RNA, cholesterol, folic acid, etc., and development of those molecules to biological targets for reversal of MDR have become a current focus [33-39]. For example, clinical trials with folic acid and enzymes have been conducted, as shown in Table 5 (No. $1,5,25)$. It is worth noting that invariant NKT cells, a lymphocyte lineage with features of both $\mathrm{T}$ and NK cells, can significantly enhance the cytotoxicity induced by cisplatin, doxorubicin and methotrexate on osteosarcoma cells [40]. T-cell transplantation has advantages in metastatic paediatric sarcomas treatment (Table 5; No. 36). Efforts to actively reveal additional potential molecular mechanisms of MDR, develop novel molecular-targeted drugs depending on the related signalling pathways, and conduct drug evaluation experiments are expected to remain a hot topic from past and present to the future.

Cluster 6 focuses on drug discovery of Chinese herbal extracts that interfere with apoptosis of tumour cells. As described in the previous paragraph, chemoresistance of osteosarcoma is the most prominent clinical dilemma. Recently, traditional Chinese medicines have become increasingly vital in treatment of tumours and are a good source of new anticancer drugs due to advantages of fewer side effects and the absence of chemoresistance [41]. For instance, eribulin mesylatein has been applied to clinical trial (Table 5' No. 4). Tracing back through the past decade of traditional Chinese medicine studies on osteosarcoma, we found that many of them focused on interfering with the apoptosis of tumour cells, which was considered as the main way to eradicate cancer, and several natural ingredients with potential clinical applications have been explored, such as celastrol, honokiol, berberine, chamaejas-mine and artemisinin [42-46]. In addition, natural compounds responded well to cell cycle arrest and apoptosis with increased reactive oxygen species and could improve the 5-year survival rate. Therefore, it is necessary to find additional Chinese herbal extracts that regulate the oxidative stress level to intervene in the apoptosis of osteosarcoma cells.

Cluster 7 addresses drug discovery of Chinese herbal extracts that interfere with autophagy of tumour cells. It is well known that autophagy-induced cell death is another important indicator for evaluating anticancer drugs in addition to apoptosis. In fact, autophagy can promote cell survival and lead to cell death $[47,48]$. This critical process of autophagy is deregulated in 
osteosarcoma, but it can be induced [49]. Consistently, regulation of tumour cell autophagy by natural Chinese herbal medicine ingredients is also a current hot topic with substances such as riccardin and celastrol $[45,50]$. Notably, autophagy is still highly related to MDR and prognosis of osteosarcoma, which further solidifies the discoverability among osteosarcoma chemoresistance, traditional Chinese medicine extracts and autophagy [51]. The occurrence of osteosarcoma does not follow a simple pattern. The complexity of the genome promotes the drug resistance of osteosarcoma and supplies infinite possibilities for new medicine. Phenotypic screening of various active ingredients in natural Chinese herbal medicine is expected to promote the development of new compounds based on apoptosis and autophagy.

Nevertheless, we were aware of several potential limitations of this study. First, those novel and less-focused $\mathrm{MeSH}$ terms may not be involved. Second, the number of related papers on osteosarcoma and cure may increase rapidly, that the constant updating of the database may lead to a difference between the bibliographic analysis data and the actual research progress. Finally, the error of the database itself may lead to a deviation of the result, such as Web of Science may mislabel document types, so that the dataset may contain papers that should be filtered out and miss papers that should be included.

\section{Conclusions}

In our study, we collected new ideas on the metastasis pattern of osteosarcoma, emphasizing the abnormality of the tumour microenvironment genetics. The existence and prevalence of multi-drug resistance make the emergence of new alternative tactics and multi-dimensional evaluation systems to replace systemic chemotherapy a crucial effort. Ongoing clinical trials and a 10-year literature search also corroborated that the development of novel drugs to overcome chemoresistance is a top priority, and extracts from traditional Chinese medicine offer new resources. Overall, we believe that this article is of guiding significance for osteosarcoma and that the above hotspots might contribute to a breakthrough in the future.

\section{Abbreviations}

BICOMB: Bibliographic item co-occurrence matrix builder: MeSH: Medical Subject Headings; MDR: multi-drug resistance; MSCs: mesenchymal stem cells

\section{Acknowledgements}

Not applicable.

\section{Authors' contributions}

(I) Conception and design: LT;(II) Administrative support: LT;(III) Provision of study materials or patients: LT;(IV) Collection and assembly of data: WCLD, YM; ZBT;(V) Data analysis and interpretation: SMZ, KCW, KDY; (VI) Manuscript writing: All authors (VII) Final approval of manuscript: All authors.
Funding

Not applicable.

\section{Availability of data and materials}

The datasets supporting the conclusions of this article are available from the corresponding authors upon reasonable request.

Ethics approval and consent to participate

Not applicable.

Consent for publication

Not applicable.

\section{Competing interests}

The authors declare that there are no conflicts of interest.

Received: 9 November 2020 Accepted: 18 January 2021

Published online: 04 February 2021

References

1. Anderson ME. Update on survival in osteosarcoma. Orthop Clin North Am. 2016:47(1):283-92

2. Jawad MU, Cheung MC, Clarke J, Koniaris LG, Scully SP. Osteosarcoma: improvement in survival limited to high-grade patients only. J Cancer Res Clin Oncol. 2011;137(4):597-607.

3. Jiang F, Shi Y, Li GJ, Zhou F. A meta-analysis of limb-salvage versus amputation in the treatment of patients with Ennekingdouble daggerU pathologic fracture osteosarcoma. Indian J Cancer. 2015;51(Suppl 2):e21-4.

4. Ando K, Heymann MF, Stresing V, Mori K, Redini F, Heymann D. Current therapeutic strategies and novel approaches in osteosarcoma. Cancers. 2013;5(2):591-616.

5. Khan MS, Ullah W, Riaz IB, Bhulani N, Manning WJ, Tridandapani S, Khosa F. Top 100 cited articles in cardiovascular magnetic resonance: a bibliometric analysis. J Cardiovasc Magn Reson. 2016;18(1):87.

6. Gao Y, Wang Y, Zhai X, He Y, Chen R, Zhou J, Li M, Wang Q. Publication trends of research on diabetes mellitus and T cells (1997-2016): a 20-year bibliometric study. PLoS One. 2017;12(9):e0184869.

7. Zhou S, Tao Z, Zhu Y, Tao L. Mapping theme trends and recognizing hot spots in postmenopausal osteoporosis research: a bibliometric analysis. PeerJ. 2019;7:e8145

8. Tao LZS, Tao Z, Wen K, Da W, Meng Y, Zhu Y. The publication trends and hot spots of scoliosis research from 2009 to 2018: a 10-year bibliometric analysis. Ann Transl Med. 2020;8(6):365.

9. Li F, Li M, Guan P, Ma S, Cui L. Mapping publication trends and identifying hot spots of research on internet health information seeking behavior: a quantitative and co-word biclustering analysis. J Med Internet Res. 2015; 17(3):e81.

10. Landis JR, Koch GG. The measurement of observer agreement for categorical data. Biometrics. 1977;33(1):159-74.

11. Aljarf A, Amin S, Filippas J, Shuttelworth J. The Development of an Images Detection System Based on Extracting the Colour Gradient Co-occurrence Matrix Features. In: 2016 9th International Conference on Developments in eSystems Engineering (DeSE): 2016; 2016.

12. Chen C, Ibekwe-SanJuan F, Hou J. The structure and dynamics of cocitation clusters: A multiple-perspective cocitation analysis. J Am Soc Inform Sci Technol. 2010;61(7):1386-409.

13. Chen C. CiteSpace II: Detecting and visualizing emerging trends and transient patterns in scientific literature. J Am Soc Inform Sci Technol. 2006; 57(3):359-77.

14. Isakoff MS, Bielack SS, Meltzer P, Gorlick R. Osteosarcoma: current treatment and a collaborative pathway to success. J Clin Oncol. 2015;33(27):3029-35.

15. Pirayesh E, Rakhshan A, Amoui M, Rakhsha A, Poor AS, Assadi M. Metastasis of femoral osteosarcoma to the abdominal wall detected on 99m Tc-MDP skeletal scintigraphy. Ann Nucl Med. 2013:27(5):478-80.

16. Theriault RL, Theriault RL. Biology of bone metastases. Cancer Control. 2012; 19(2):92-101.

17. Schrager J, Patzer RE, Mink PJ, Ward KC, Goodman M. Survival outcomes of pediatric osteosarcoma and Ewing's sarcoma: a comparison of surgery type within the SEER database, 1988-2007. J Registry Manag. 2011;38(3):153-61.

18. Kamal AF, Widyawarman H, Husodo K, Hutagalung EU, Rajabto W. Clinical outcome and survival of osteosarcoma patients in Cipto Mangunkusumo 
hospital: limb salvage surgery versus amputation. Acta medica Indonesiana. 2016:48(3):175-83.

19. Anwar MA, El-Baba C, Elnaggar MH, Elkholy YO, Mottawea M, Johar D, Al Shehabi TS, Kobeissy F, Moussalem C, Massaad E, et al. Novel therapeutic strategies for spinal osteosarcomas. Semin Cancer Biol. 2019;64:83-92.

20. Bischoff I, Tsaryk R, Chai F, Furst R, Kirkpatrick CJ, Unger RE. In vitro evaluation of a biomaterial-based anticancer drug delivery system as an alternative to conventional post-surgery bone cancer treatment. Mater Sci Eng C Mater Biol Appl. 2018;93:115-24.

21. Yu W, Liu Z, Tang L, Lin F, Yao Y, Shen Z. Efficacy and safety of stereotactic radiosurgery for pulmonary metastases from osteosarcoma: experience in 73 patients. Sci Rep. 2017;7(1):17480.

22. Zhang W, Tanaka M, Sugimoto Y, Takigawa T, Ozaki T. Carbon-ion radiotherapy of spinal osteosarcoma with long-term follow. Eur Spine J. 2016;25(Suppl 1):113-7.

23. Zhao Y, Tu MJ, Yu YF, Wang WP, Chen QX, Qiu JX, Yu AX, Yu AM. Combination therapy with bioengineered miR-34a prodrug and doxorubicin synergistically suppresses osteosarcoma growth. Biochem Pharmacol. 2015; 98(4):602-13.

24. Nugent M. MicroRNA function and dysregulation in bone tumors: the evidence to date. Cancer Manag Res. 2014;6:15-25.

25. Kim YH, Goh TS, Lee CS, Oh SO, Kim Jl, Jeung SH, Pak K. Prognostic value of microRNAs in osteosarcoma: a meta-analysis. Oncotarget. 2017;8(5):8726-37.

26. Tu B, Zhu J, Liu S, Wang L, Fan Q, Hao Y, Fan C, Tang TT. Mesenchymal stem cells promote osteosarcoma cell survival and drug resistance through activation of STAT3. Oncotarget. 2016;7(30):48296-308.

27. Rici REG, Will S, Luna ACL, Melo LF, Santos AC, Rodrigues RF, Leandro RM, Maria DA. Combination therapy of canine osteosarcoma with canine bone marrow stem cells, bone morphogenetic protein and carboplatin in an in vivo model. Vet Comp Oncol. 2018;16(4):478-88.

28. Duchi S, Sotgiu G, Lucarelli E, Ballestri M, Dozza B, Santi S, Guerrini A, Dambruoso P, Giannini S, Donati D, et al. Mesenchymal stem cells as delivery vehicle of porphyrin loaded nanoparticles: effective photoinduced in vitro killing of osteosarcoma. J Controlled Release. 2013;168(2):225-37.

29. Qiao B, Shui W, Cai L, Guo S, Jiang D. Human mesenchymal stem cells as delivery of osteoprotegerin gene: homing and therapeutic effect for osteosarcoma. Drug Design Dev Ther. 2015;9:969-76.

30. Shah K. Mesenchymal stem cells engineered for cancer therapy. Adv Drug Deliv Rev. 2012;64(8):739-48.

31. Whelan JS, Jinks RC, McTiernan A, Sydes MR, Hook JM, Trani L, Uscinska B, Bramwell V, Lewis IJ, Nooij MA, et al. Survival from high-grade localised extremity osteosarcoma: combined results and prognostic factors from three European osteosarcoma intergroup randomised controlled trials. Ann Oncol. 2012;23(6):1607-16.

32. Botter SM, Neri D, Fuchs B. Recent advances in osteosarcoma. Curr Opin Pharmacol. 2014;16:15-23.

33. Kun-Peng Z, Xiao-Long M, Chun-Lin Z. Overexpressed circPVT1, a potential new circular RNA biomarker, contributes to doxorubicin and cisplatin resistance of osteosarcoma cells by regulating ABCB1. Int J Biol Sci. 2018; 14(3):321-30.

34. Xu R, Liu S, Chen H, Lao L. MicroRNA-30a downregulation contributes to chemoresistance of osteosarcoma cells through activating Beclin-1mediated autophagy. Oncol Rep. 2016;35(3):1757-63.

35. Shaikh AB, Li F, Li M, He B, He X, Chen G, Guo B, Li D, Jiang F, Dang L, et al. Present advances and future perspectives of molecular targeted therapy for osteosarcoma. Int J Mol Sci. 2016;17(4):506.

36. Li Z, Zhao L, Wang Q. Overexpression of long non-coding RNA HOTTIP increases chemoresistance of osteosarcoma cell by activating the Wnt/betacatenin pathway. Am J Transl Res. 2016;8(5):2385-93.

37. Zhang Y, Duan G, Feng S. MicroRNA-301a modulates doxorubicin resistance in osteosarcoma cells by targeting AMP-activated protein kinase alpha 1. Biochem Biophys Res Commun. 2015;459(3):367-73.

38. Feng $T$, Qiao G, Feng L, Qi W, Huang Y, Yao Y, Shen Z. Stathmin is key in reversion of doxorubicin resistance by arsenic trioxide in osteosarcoma cells. Mol Med Rep. 2014;10(6):2985-92.

39. Lannutti F, Marrone A, Re N. Binding of GSH conjugates to pi-GST: a crossdocking approach. J Mol Graphics Model. 2012;32:9-18.

40. Fallarini S, Paoletti T, Orsi Battaglini N, Lombardi G. Invariant NKT cells increase drug-induced osteosarcoma cell death. Br J Pharmacol. 2012;167(7):1533-49.

41. Yarla NS, Bishayee A, Sethi G, Reddanna P, Kalle AM, Dhananjaya BL, Dowluru KS, Chintala R, Duddukuri GR. Targeting arachidonic acid pathway by natural products for cancer prevention and therapy. Semin Cancer Biol. 2016;40-41:48-81.

42. Huang $K$, Chen Y, Zhang R, Wu Y, Ma Y, Fang X, Shen S. Honokiol induces apoptosis and autophagy via the ROS/ERK $1 / 2$ signaling pathway in human osteosarcoma cells in vitro and in vivo. Cell Death Dis. 2018;9(2):157.

43. Jin $\mathrm{H}$, Jin X, Cao B, Wang W. Berberine affects osteosarcoma via downregulating the caspase-1//L-1 beta signaling axis. Oncol Rep. 2017;37(2): 729-36.

44. Yang $D$, Wang $P$, Ren $X$. Apoptosis induced by chamaejasmine in human osteosarcoma cells through p53 pathway. Tumour Biol. 2015;36(7):5433-9.

45. Li HY, Zhang J, Sun LL, Li BH, Gao HL, Xie T, Zhang N, Ye ZM. Celastrol induces apoptosis and autophagy via the ROS/JNK signaling pathway in human osteosarcoma cells: an in vitro and in vivo study. Cell Death Dis. 2015;6:e1604.

46. Ji Y, Zhang YC, Pei LB, Shi LL, Yan JL, Ma XH. Anti-tumor effects of dihydroartemisinin on human osteosarcoma. Mol Cell Biochem. 2011;351(12):99-108.

47. Min L, Choy E, Pollock RE, Tu C, Hornicek F, Duan Z. Autophagy as a potential target for sarcoma treatment. Biochim Biophys Acta Rev Cancer. 2017;1868(1):40-50

48. Li J, Yang Z, Li Y, Xia J, Li D, Li H, Ren M, Liao Y, Yu S, Chen Y, et al. Cell apoptosis, autophagy and necroptosis in osteosarcoma treatment. Oncotarget. 2016;7(28):44763-78.

49. O'Farrill JS, Gordon N. Autophagy in osteosarcoma. Adv Exp Med Biol. 2014; 804:147-60.

50. Wang Y, Ji Y, Hu Z, Jiang H, Zhu F, Yuan H, Lou H. Riccardin D induces cell death by activation of apoptosis and autophagy in osteosarcoma cells. Toxicol In Vitro. 2013;27(6):1928-36.

51. Livingston JA, Wang WL, Tsai JW, Lazar AJ, Leung CH, Lin H, Advani S, Daw N, Santiago-O'Farrill J, Hollomon M, et al. Analysis of HSP27 and the autophagy marker LC3B(+) Puncta following preoperative chemotherapy identifies high-risk osteosarcoma patients. Mol Cancer Ther. 2018;17(6): $1315-23$.

\section{Publisher's Note}

Springer Nature remains neutral with regard to jurisdictional claims in published maps and institutional affiliations.
Ready to submit your research? Choose BMC and benefit from:

- fast, convenient online submission

- thorough peer review by experienced researchers in your field

- rapid publication on acceptance

- support for research data, including large and complex data types

- gold Open Access which fosters wider collaboration and increased citations

- maximum visibility for your research: over $100 \mathrm{M}$ website views per year

At BMC, research is always in progress.

Learn more biomedcentral.com/submissions 